\title{
Development of the Pilot Resilience Scale (Employees, Leaders and Teams)
}

\author{
Barcenilla González MÁ1*, Del Rey-Mejías ÁL², Duran-Cutilla M1, \\ González-Peñas J1 ${ }^{1}$ Huete MA $^{1}$ and Merchán-Naranjo J ${ }^{1}$ \\ 1Department of Child and Adolescent Psychiatry, Hospital GU Gregorio Marañón, Spain \\ and European School of Training and Research in HR (EEFRH), Spain \\ ${ }^{2}$ Innovation Unit, Hospital Clinico San Carlos, Department of Methodology, Universidad \\ Complutense, Spain
}

\section{Research Article}

Volume 2 Issue 1

Received Date: March 12, 2018

Published Date: May 16, 2018

DOI: $10.23880 / \mathrm{mhrij}-16000117$

*Corresponding author: Ángeldel Rey Mejías and Miguel Barcenilla, Department of Child and Adolescent Psychiatry, Hospital GU Gregorio Marañón, IiSGM, Madrid, Spain and European School of Training and Research in HR (EEFRH), Madrid, Spain, Tel: 0034637864573; Email: alreymejias@gmail.com; miguelbarceni@gmail.com

\section{Abstract}

Background: In the context of resilience, the pilot resilience scale in Spanish was developed to assess resilience for workers, leaders and teams.

Method: The factorial structure of the scale was tested using exploratory and confirmatory factors analysis with a Colombian multi-occupational employee sample ( $\mathrm{N}=53)$.

Results: The reliability (internal consistency) of the scales was assessed with Cronbach's alpha: Total pilot resilience scale (0.94), individual resilience sub-scale (0.86), leadership resilience sub-scale (0.95) and team resilience sub-scale (0.84). Exploratory factor analysis (EFA) determines a structure of 5 factors that explain $46 \%$ of variance. Total: 75 items. Confirmatory factor analysis (CFA) forced to 3 factors and selecting the items up to $99 \%$ representativeness of the variability. Total: 41 items. The items were reviewed by experts in work psychology. Final pilot resilience scale includes items the highest statistical weight EFA of 5 factors and all items of CFA (removing repeated items).

Conclusions: Total 62 items to be validated in a wide sample of workers in Colombia to develop a reliable instrument to measure resilience.

Keywords: Resilience; Validation; Wellbeing at Work; Scales; Workers; Leaders; Teams

\section{Introduction}

Currently, workers, leaders and work teams face constant changes in their work environment, both internal and external, and resilience could be shown as the key resource when it comes to favoring their adaptation and well-being. 


\section{Mental Health \& Human Resilience International Journal}

The word resilience derives from Latin "resiliens" and refers to 'jump back', 'bounce back,' fall back '. It is defined as the capacity of adaptation of a living being faces a disturbing agent or an adverse state or situation as well as the capacity of a material, mechanism or system to recover its initial state when the disturbance to which it had been subjected has ceased.

\section{Individual Resilience}

The concept of Individual Resilience is defined as the individual variations in the way of responding to risk [1].

And resilience refers to a dynamic process encompassing positive adaptation within the context of significant adversity [2] and resilience refers to a class of phenomena characterized by good outcomes in spile of serious threats to adaptation or development [3].

The concept of resilience in relation to the individual is understood as the ability to overcome adversity, recover, and emerge strengthened, successful and develop social, academic and vocational competence, despite being exposed to severe psychosocial stress [4].

Other authors define resilience as the ability to overcome adversity, recover and strengthen themselves by developing favorable competencies to adapt to changes that may involve psychosocial stress [5].

In the workplace individual resilience can help workers to match the needs of the client, to take advantage of opportunities that might otherwise be lost, to act quickly and effectively in situations of threat and crisis [6].

The individual resilience measures that have been most translated and adapted to Spanish and administered to workers are CD-RISC [7] and RS [8] (Table 1).

\section{Leadership Resilience}

Resilience begins with enterprise leadership setting the priorities, allocating the resources and making the commitments to establish organizational resilience throughout the enterprise [9] (Table 2).

A measure of leadership resilience is necessary because studies have observed that with higher resilience, nurse leaders are more likely to intend to remain in their leadership positions [10].

Strong leadership that promotes cohesive and interdependent teams is a critical component of a resilient organization [11]. We emphasize the lack of scales to measure leadership resilience in English or Spanish.

\section{Team Resilience}

Organizational resilience evolves over time as management and teams adhere to the mission and to the core values of the organization [11].

To cope with life prompts, humans cultivate, through previous disruptions, resilient qualities so that most events become routine and less likely to be disruptive [12].

Extrapolating the concept of the individual to a group of people, refers to the ability of a group of people to develop a series of affinity structures in order to face and overcome an adverse situation effectively. Gilbert (2008) [13] defines it as the innate capacity to survive destruction and learn how to convert the crisis and take advantage of it for growth.

Several psychosocial factors such as the relationships involved, effective teamwork originated through cohesion, trust, inventiveness, collective efficacy and relational schemes [14] are considered the resilience characteristics of the equipment.

The researches show Resilience as providing a foundational, additive, synergistic, and complementary role to that of self-efficacy, hope and optimism, in enhancing performance and attitudinal outcomes [15].

We emphasize the development of a single scale for measuring team resilience in English [16] and no team resilience scale developed in Spanish. To talk about Resilience workers, leaders and teams must have suffered threats or risks. There are specific resilience scales for workers and teams, mostly in English. (Table 3)

\section{Hypothesis}

The Resilience construct in workers involves 3 factors to measure (1. Individual resilience, 2. Leadership resilience and 3. Team resilience).

\section{Objective}

The aim and novelty of this study consists in the development of a pilot resilience scale in Spanish that measures 3 aspects of workplace resilience (1. Individual resilience, 2 . Leadership resilience and 3 . Team resilience) and examines its psychometric properties. 


\section{Mental Health \& Human Resilience International Journal}

Literature Review

\begin{tabular}{|c|c|c|}
\hline SCALE & FATOR / DIMENSIONS & REFERENCE \\
\hline $\begin{array}{c}\text { RAW } \\
\text { (Resilience at work) }\end{array}$ & $\begin{array}{c}\text { Living authentically } \\
\text { Maintaining perspective }\end{array}$ & (Winwood, et al. 2013) [17] \\
\hline $\begin{array}{c}\text { WRI } \\
\text { (Workplace Resilience Inventory) }\end{array}$ & $\begin{array}{c}\text { Personal characteristics, } \\
\text { Resources and Self-regulation }\end{array}$ & (Sharma, et al. 2016) [16] \\
\hline $\begin{array}{c}\text { Team Resilience: Scale } \\
\text { Development and Validation }\end{array}$ & $\begin{array}{c}\text { Group structure, social capital } \\
\text { and collective efficacy }\end{array}$ & \\
\hline
\end{tabular}

Table 1: Individual and Team Resilience Scales for workers.

\begin{tabular}{|c|c|c|}
\hline SCALE & FATOR / DIMENSIONS & REFERENCE \\
\hline $\begin{array}{c}\text { BRT-13 } \\
\text { (Benchmark Resilience tool }\end{array}$ & Planning and Adaptive capacity & (Whitman, et al. 2013) [19] \\
\hline $\begin{array}{c}\text { Assessing behaviors that create resilient } \\
\text { organizations }\end{array}$ & $\begin{array}{c}\text { Strategic planning and organizational } \\
\text { learning }\end{array}$ & (Home, et al. 1997)[20] \\
\hline $\begin{array}{c}\text { Developing a tool to measure and compare } \\
\text { organizations' resilience }\end{array}$ & Planning and Adaptivecapacity & (Lee, et al. 2013) [21] \\
\hline
\end{tabular}

Table 2: Organizational Resilience Scales.

\begin{tabular}{|c|c|}
\hline SCALE & SPANISH ADAPTATION \\
\hline \multirow{3}{*}{$\begin{array}{c}\text { CD-RISC } \\
\text { The Connor-Davidson resilience scale } \\
(2003)^{\mathrm{g}}\end{array}$} & $\begin{array}{l}\text { Spanish adaptation (CD-RISC) in situations of chronic stress. } \\
\text { (Crespo, et al. 2013) [22] }\end{array}$ \\
\hline & $\begin{array}{l}\text { Psychometric properties of (CD-RISC) in a Spanish sample of } \\
\text { entrepreneurs. } \\
\text { (Manzano-García, et al. 2013) [23] }\end{array}$ \\
\hline & $\begin{array}{c}\text { Psychometric properties (10-item CD-RISC) in a sample of } \\
\text { workers. (Sánchez, et al. 2016) [24] }\end{array}$ \\
\hline $\begin{array}{c}\text { RS } \\
\text { The resilience Scale Wagnild and Young }(1993)^{\mathrm{h}}\end{array}$ & $\begin{array}{c}\text { Validation and Spanish adaptation of the scale of resilience in } \\
\text { the sports context (ERCD). } \\
\text { (Trigueros, et al. 2017) [25] }\end{array}$ \\
\hline
\end{tabular}

Table 3: Resilience Scales adapted to Spanish for workers.

\section{Materials \& Methods}

Design: Cross-sectional study.

Participants

The participants were 53 Colombians workers in different industrial, commercial, educational and service organizations that accepted voluntary participation in the study. 37 Resilience scales were selected in the literature review. 3 Factors to study: Factor 1: Individual Resilience. Factor 2: Leadership Resilience and Factor 3: Team Resilience.

Item construction: The research team built the Pilot Resilience Scale with 312 items and the questions were reviewed by experts in work psychology. 137 item included in Factor 1 and 111 item included in Factor 2 and 64 item included in Factor 3. Format: Self-application scale.

Data collect: Participants were asked to indicate their agreement with the items on a seven-point Likert response scale $(1=$ "strongly disagree" to $7=$ "strongly agree") through a survey accessed online.

Examples of items included of the pilot scale to measure Individual Resilience (Spanish version and English translation):

1. Me siento orgulloso con el trabajo que realizo. I am proud the work I do.

2. Me siento capacitado para nuevos retos. I feel qualified for new challenges.

3. Afronto las dificultades como desafíos y oportunidades para aprender. 


\section{Mental Health \& Human Resilience International Journal}

I face difficulties as challenges and opportunities to learn.

$4 . \quad$ Soy eficiente en mi trabajo.

I am efficient in my work.

5. Puedo desarrollar mis competencias profesionales en el trabajo.

I can develop my professional skills at work.

6. $\quad$ Me implico en la calidad de mi trabajo.

I get involved in the quality of my work.

7. Me afectan personalmente los fallos en el trabajo.

Personal failures affect me personally.

8. Después de una dificultad mantengo una perspectiva positiva.

After a difficulty I maintain a positive outlook.

9. $\quad$ Evalúo mis reacciones después de una situación de tensión.

I evaluate my reactions after a stressful situation.

$10 . \quad$ Realizo ejercicio físico todas las semanas.

I do physical exercise every week.

Examples of items included of the pilot scale to measure Leader Resilience (Spanish version and English translation):

11. Mi jefe me anima a ser creativo e innovador en la resolución de problemas.

My boss encourages me to be creative and innovative in solving problems.

12. Puedo expresar con libertad mi inconformidad sobre ciertas decisiones de mi jefe.

I can freely express my disagreement about certain decisions of my boss.

13. 13. $\mathrm{Mi}$ jefe me cuida $\mathrm{y}$ entiende mis sentimientos.

My boss takes care of me and understands my feelings.

$14 . \quad 14$. Mi jefe me apoya en las dificultades.

My boss backs me in the difficulties

15. 15. Me proponen retos para desarrollar mi creatividad.

My boss challenges me to develop my creativity.

$16 . \quad 16$. Se valora la calidad de mi trabajo.

The quality of my work is valued.

Examples of items included of the pilot scale to measure Team Resilience (Spanish version and English translation):

17. Se resuelven fácilmente los conflictos entre los miembros del equipo.

Conflicts between team members are easily resolved.

18. Los compañeros del equipo son flexibles para superar las dificultades.
Teammates are flexible to overcome difficulties.

19. 19. Los compañeros se responsabilizan de los problemas hasta que se resuelven.

The partners are responsible for the problems until they are resolved.

20. 20. Mis compañeros toman en cuenta mis necesidades en la toma de decisiones importantes.

My colleagues take into account my needs in making important decisions.

$21 . \quad 21$. El trabajo de mi equipo es significativo.

The work of my team is significant.

\section{Statistical Analysis}

The factorial structure of the scale was tested using exploratory factor analysis (EFA) where 312 resilience items were examined using the reduction dimension and confirmatory factor analysis (CFA) forced extraction of 3 factors (Item analyzed by stepwise method (introducing factors) in a multiple linear regression model and item selection up to $99 \%$ of variability. Correlations among factors were studied. Statistical analyses were conducted using SPSS v.22.0.

\section{Results}

53 Workers from companies of Colombia were included in the study. 56.6\% Women and $43.4 \%$ Men. Mean age of 42.25 years. Occupational risk (low level): $64.2 \%$. Married: $52.8 \%$ and with a children $=35.8 \%$ (Figures 1-4).

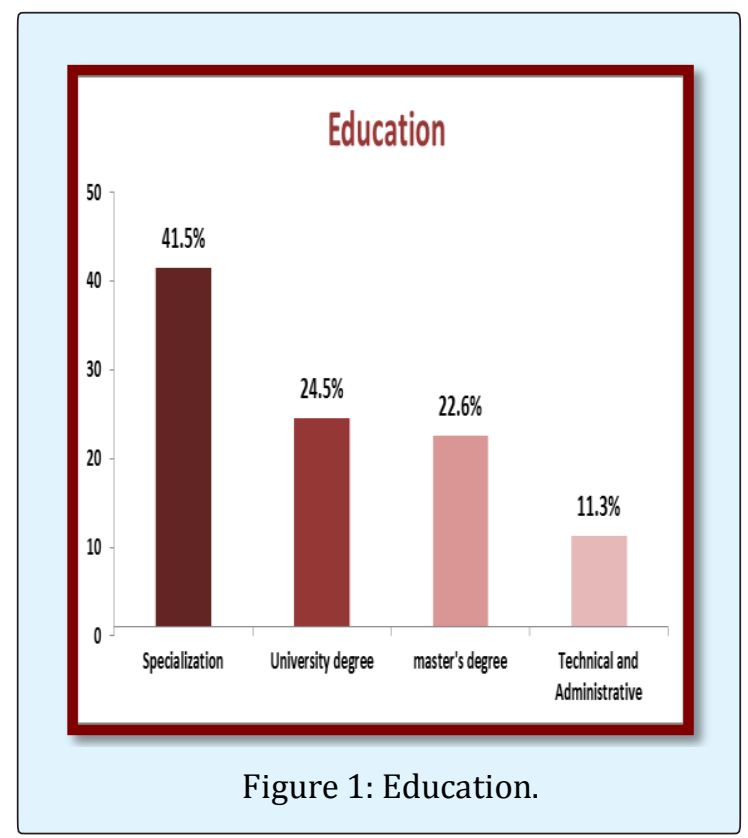



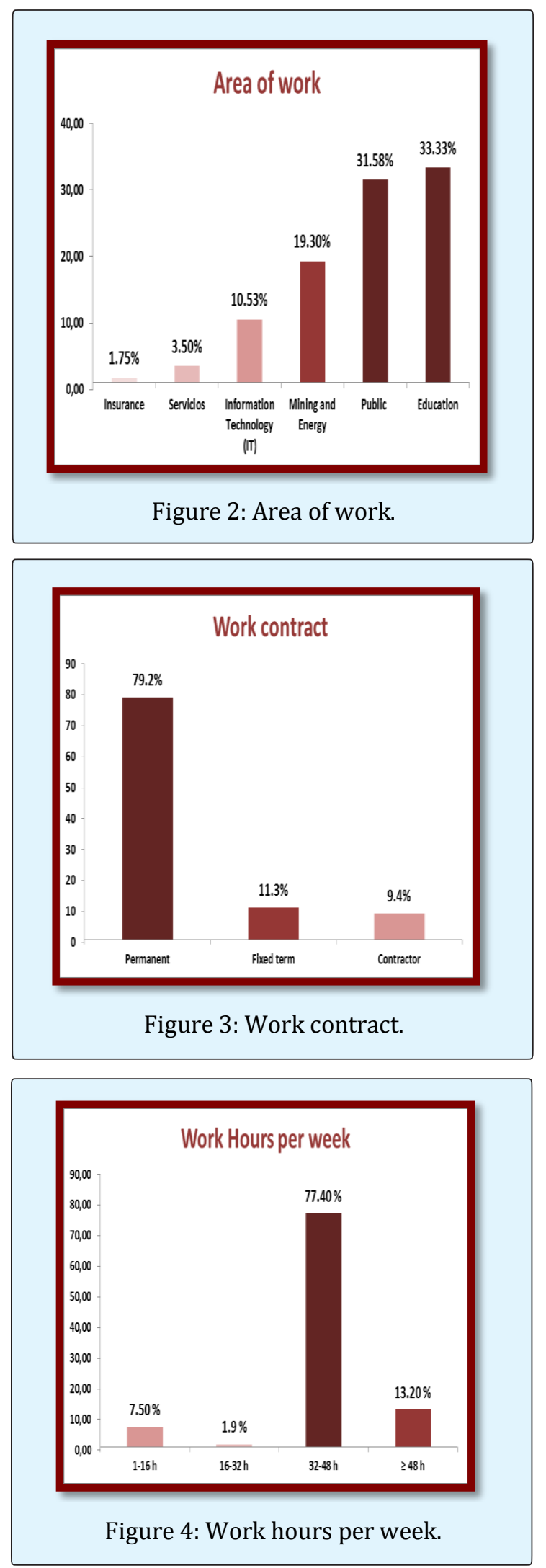

Then, the reliability (internal consistency) of the scales was assessed with Cronbach's alpha: Total pilot resilience scale (0.94), individual resilience sub-scale (0.86), leadership resilience sub-scale $(0.95)$ and team resilience sub-scale (0.84).

Exploratory factor analysis (EFA) determines a structure of 5 factors that explain $46 \%$ of variance. Total: 75 items. Confirmatory factor analysis (CFA) forced to 3 factors and selecting the items up to $99 \%$ representativeness of the variability. Total: 41 items. The analysis indicate that 75 items of EFA explain $46 \%$ variance and 41 items of CFA explain $99 \%$ of variance, specifically, Factor 1: Individual Resilience subscale (137 items tested and 13 items provide $99 \%$ of the variability), Factor 2: Leadership Resilience subscale (111 items tested and 13 items provide $99 \%$ of the variability) and Factor 3: Team Resilience subscale (64 items tested and 13 items provide $99 \%$ of the variability) (Figure 5).

The 3 factors have a direct and positive relationship, being the highest between leadership resilience and team resilience (35\% shared variance) and the lowest between leadership resilience and individual resilience $(22 \%$ shared variance) (Table 6).

The items were reviewed by experts in work psychology, experts in neuropsychology and methodologists that recommended including in the final Pilot Resilience Scale items with the highest statistical weight of the EFA of 5 factors and all items of CFA (removing repeated items).

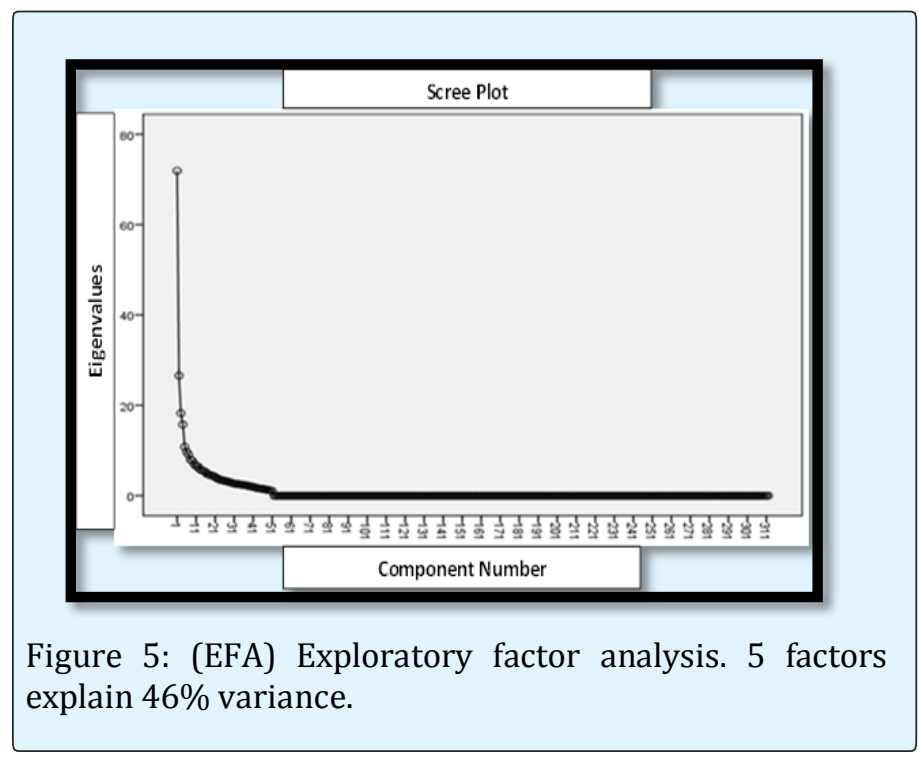




\section{Mental Health \& Human Resilience International Journal}

\begin{tabular}{|c|c|c|c|}
\hline \multicolumn{4}{|c|}{ Correlations } \\
\hline & Individual Resilience & $\begin{array}{l}\text { Leadership } \\
\text { Resilience }\end{array}$ & Team Resilience \\
\hline $\begin{array}{c}\text { Individual Resilience Pearson Correlation } \\
\text { Sig. (2-tailed) } \\
\text { N }\end{array}$ & $\begin{array}{c}1 \\
53\end{array}$ & $\begin{array}{l}0.468^{* *} \\
.000 \\
53\end{array}$ & $\begin{array}{l}.535^{* *} \\
.000 \\
53\end{array}$ \\
\hline $\begin{array}{c}\text { Leadership Resilience Pearson Correlation } \\
\text { Sig. (2-tailed) } \\
\text { N }\end{array}$ & $\begin{array}{l}.468^{* *} \\
. \text { CCO } \\
53\end{array}$ & $\begin{array}{c}1 \\
53\end{array}$ & $\begin{array}{l}.587^{* *} \\
.000 \\
53\end{array}$ \\
\hline $\begin{array}{c}\text { Team Resilience Pearson Correlation } \\
\text { Sig. (2-tailed) } \\
\text { N }\end{array}$ & $\begin{array}{l}.535^{* *} \\
. \text { CCO } \\
53\end{array}$ & $\begin{array}{l}.587^{* *} \\
.000 \\
53\end{array}$ & $\begin{array}{c}1 \\
53\end{array}$ \\
\hline \multicolumn{4}{|c|}{ **. Correlation is significant at the 0.01Ieve (2-tailed). } \\
\hline
\end{tabular}

Table 6: Correlations show that the 3 factors have a direct and positive relationship.

\section{Discussion}

The objective of this study has been the development of a scale to assess the resilience of workers and the analysis of their psychometric properties. The aim was to build a scale that would allow measuring resilience in different jobs belonging to different labor sectors. For this reason, it was necessary that the instrument be easy to apply and focus specifically on the evaluation of the workers' resilience construct. The results of this research show that the present measure of resilience is organized into five factors or three factors according to the statistical analysis.Our hypothesis suggests the organization of the Resilience construct of workers in 3 factors resilience 1 . Individual resilience, 2. Leadership resilience and 3. Team resilience).

The final pilot resilience scale includes 62 items to be validated in a wide sample, to a minimum of 10 participants per item, of workers in Colombia. This study also presents limitations that should be indicated. We must emphasize that we are in the first phase of development of the instrument and, consequently, new studies confirming the structural validity must be carried out. The resilience valuations produced by this instrument must also be contrasted with external criteria and with other subjective scales that measure the same constructs or dimensions. Another limitation comes from the sample used, it is necessary that it be more extensive, varied and representative of more areas of works.

\section{Acknowledgements}

This work was supported by funding of the POSITIVAINSURANCE COMPANY from Colombia. Human Staff from Colombia. Escuela Europea de Formación e Investigación en RRHH (EEFIRH) from Spain.

\section{References}

1. Rutter M (1985) Resilience in the face of adversity. Protective factors and resistance to psychiatric disorder. Br J Psychiatry 147(6): 598-611.

2. Luthar SS, Cicchetti D, Becker B (2000) The construct of resilience: A critical evaluation and guidelines for future work. Child Dev 71(3): 543-562.

3. Masten AS (2001) Ordinary magic: Resilience processes in development. Am psychol 56(3): 227238.

4. Grotberg EH (2001) Resilience programs for children in disaster. Ambulatory Child Health 7(2): 75-83.

5. Eachus P (2014) Community Resilience: Is it greater tan the sum of the parts of individual resilience?. Procedia Economics and finance 18: 345-351.

6. Meneghel I, Salanova M, Martínez IM (2013) El camino de la Resiliencia Organizacional-Una revisión teórica. Aloma: Revista de Psicologia, Ciències de l'Educació i de l'Esport 31(2): 13-24. 


\section{Mental Health \& Human Resilience International Journal}

7. Connor KM, Davidson JR (2003) Development of a new Resilience scale: The Connor-Davidson Resilience scale (CD-RISC). Depression and anxiety 18(2): 76-82.

8. Wagnild GM, Young HM (1993) Development and psychometric evaluation of the Resilience Scale.J Nurs Meas 1(2): 165-178.

9. Bell MA (2002) The five principles of organizational resilience. Gartner.

10. Hudgins TA (2016) Resilience, job satisfaction and anticipated turn over in nurse leaders. J nurs manag 24(1): 62-69.

11. Southwick FS, Martini BL, Charney DS, Southwick SM (2017) Leadership and resilience. In: Marques, et al. (eds.), Leadership today, Springer, pp: 315-333.

12. Richardson GE (2002) The metatheory of resilience and resiliency. Journal of clinical psychology 58(3): 307-321.

13. Gilbert M (2008) Bridging the gap: Building local resilience and competencies in remote communities. Prehosp Disaster Med 23(4): 297-300.

14. Lengnick-Hall CA, Beck TE, Lengnick-Hall ML (2011) Developing a capacity for organizational Resilience through strategic human resource management. Human Resource Management Review 21(3): 243255.

15. Youssef CM (2004) Resiliency development of organizations, leaders and employees: Multi-level theory building and individual-level, path-analytical empirical testing. University of Nebraska.

16. Sharma S, Sharma SK (2016) Team Resilience: Scale Development and Validation. Vision: The Journal of Business Perspective 20(1): 37-53.

17. Winwood, Peter C, Rochelle Colon, Kath Mc Ewen (2013) A practical measure of work place resilience:
Developing the resilience at work scale. Journal of Occupational and Environmental Medicine 55(10): 1205-1212.

18. Mc Larnon, Matthew JW, Mitchell G Rothstein (2013) Development and initial validation of the Workplace Resilience Inventory. Journal of Personnel Psychology 12(2): 63-73.

19. Whitman Zach R, Kachali Hlekiwe, Roger Derek, Vargo John, Seville Erica (2013) Short-form version of the Bench mark Resilience Tool (BRT-53). Measuring Business Excellence 17(3): 3-14.

20. Home JF, Orr JE (1997) Assessing behaviors that create resilient organizations. Employment Relations Today 24(4): 29-39.

21. Lee AV, Vargo J, Seville E (2013) Developing a tool to measure and compare organizations' resilience. Natural hazardsreview 14(1): 29-41.

22. Crespo M, Fernández-Lansac V, Soberón C (2014) Adaptación española de la" Escala de resiliencia de Connor-Davidson"(CD-RISC) en situaciones de estrés crónico. Psicología Conductual 22(2): 219-238.

23. Manzano-García G, Ayala Calvo JC (2013) Psychometric properties of Connor-Davidson Resilience Scale in a Spanish sample of entrepreneurs. Psicothema 25(2): 245-251.

24. Soler Sánchez MI, Meseguer de Pedro M, García Izquierdo M (2016) Psychometric properties of the Spanish version of the 10-item Connor-David son Resilience scale (10-item CD-RISC) in a sample of workers. Revista Latinoamericana de Psicología 48(3): 159-166.

25. Trigueros R, Álvarez JF, Aguilar-Parra JM, AlcarazIbáñez M, Rosado A (2017) Validación y adaptación española de la escala de resiliencia en el contexto deportivo (ERCD). Psychology Society \& Education 9(2): 311-324.

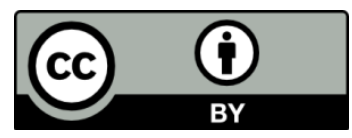

Barcenilla González MÁ, et al. Development of the Pilot Resilience Scale (Employees, Leaders and Teams). Ment Health Hum Resilience Int J 2018, 2(1): 000117. 